\title{
The preparation of a 'metal-free' nappy and its application to metabolic balances in children
}

\author{
F. W. ALEXANDER AND H. T. DELVES \\ From the Department of Chemical Pathology, Institute of Child Health, London
}

SYNOPSIS Disposable nappies (diapers) have been satisfactorily demineralized and used for the collection of excreta from infants and young children during mineral and trace metal balances. It was possible to investigate children of both sexes without immobilization.

The coliection of excreta from infants and young children during metabolic balances is difficult since they wear nappies and are so active. A further complication when the study is concerned with trace metals is the risk of contamination during sample collection.

Previous workers, studying trace elements, have tackled the problem in different ways. Berfenstam (1952) completely ignored the urinary excretion. Widdowson (1965) used 'stick-on' polyethylene bags in neonates but there is a high risk of contamination and only boys can be studied. She used brushed nylon deionized nappies to collect the faeces, which were then removed from the nappy by a complicated process of scrubbing in a stream of hot hydrochloric acid solution. McCance, Rutishauser, and Boozer (1970) immobilized their children by strapping them into metabolic chairs. Again only boys were studied and urine was drawn off using a suitable appliance strapped to the penis. The faeces were collected into a stainless steel bowl under the chair. This method of collection is unsatisfactory as it is again limited to the male sex and there is a high risk of leakage and contamination. In addition, immobilization is itself undesirable since Rose (1966) and Millard, Nassim, and Woollen (1970) have shown that it leads to an increased secretion of calcium, although it is not known whether other minerals are similarly affected.

This paper describes a method for collecting excreta which avoids both immobilization and the use of appliances attached to the child, and is suitable for boys and girls. It has been used for balance studies of calcium, magnesium, zinc, iron, copper, manganese, cadmium, cobalt, molybdenum, chromium, nickel, strontium, lead, nitrogen, phosphorus, sodium, and potassium. The method emReceived for publication 12 September 1972. ployed disposable nappies that were held in place by a specially cut plastic 'tie-pant'. Neither nappy nor 'tie-pant' could be used, as supplied, since they contained appreciable amounts of the metals being studied.

\section{Materials}

\section{A P P A R A T US}

The following are all made of polythene: buckets, 2 gal capacity, Dines containers, spatula, sheet (gauge 150), bags (15 in. $\times 12$ in.), and disposable gloves (Henleys Medical Supplies Ltd); $5 \times 201$ vats and $2 \times$ rigid polythene strips 18 in $\times 6$ in $\times \frac{1}{4}$ in (W. B. Containers Ltd). Nylon-coated wire mesh rack (Aimer Products Ltd, Camden Town, NW1) and coarse mesh nylon bags (Boots Drug Co, Nottingham Wine Dept) are also required.

These requirements were washed once with $10 \%$ $\mathrm{HNO}_{3}$ and four times with doubly deionized water before use. Polythene gloves were worn whenever the nappies were handled.

A laboratory drying oven, thermostat controlled up to $200^{\circ} \mathrm{C}$ (J. W. Towers Ltd, Widnes) is needed.

The disposable nappies (Softdown) consist of an outer non-wettable cover with an inner paper envelope wrapped around fluffed wood-pulp (Fig. 1): and the 'tie-pants' of gauge 150 polythene sheet cut

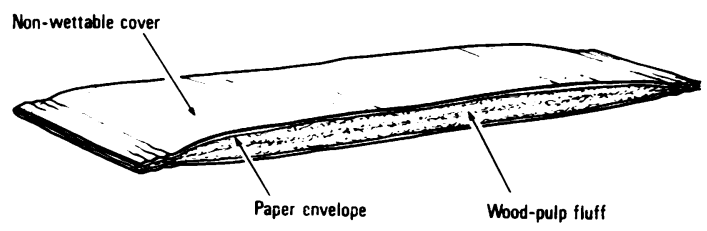

Fig. 1 Cross section of disposable nappy 
to give four corner lengths for tying, all supplied by Lewis Woolf (Griptite Ltd), Pershore, Worcestershire.

\section{REAGENTS}

Deionized water, nitric acid sp gr 1.41 Aristar grade, hydrochloric acid sp gr 1.17 Aristar grade, EDTA disodium salt Analar grade, and chloroform Analar grade (BDH Ltd, Poole, Dorset).

\section{Methods}

\section{DETERMINATION OF ELEMENTS}

Calcium, magnesium, zinc, iron, copper, manganese, cadmium, cobalt, molybdenum, chromium, nickel, strontium, and lead were determined directly using atomic absorption spectroscopy (Perkin Elmer 303) and sodium and potassium by flame emission spectroscopy using an Eppendorf flame photometer. Nitrogen was determined by a standard Kjeldahl procedure and phosphorus by the molybdenum blue method of Briggs (1922).

EXPERIMENTS ON NAPPIES AND TIE-PANTS Experiment 1: to determine the mean contamination of the diaper and 'tie-pant' by the metals

Two nappies were weighed, placed in separate polythene containers, and covered with $300 \mathrm{ml}$ of $0 \cdot 1 \mathrm{~N} \mathrm{HCl}$ solution. Two 'tie-pants' were similarly treated; a container blank was also included. After 24 hours' equilibration, the nappies and 'tie-pant' were squeezed out by hand, and the supernatant was analysed directly for the elements listed.

The contamination of the nappy was calculated with certainty for all metals except molybdenum (Table I). Assuming that six nappies were to be used per 24 hours, then for all the metals except magnesium and molybdenum, the maximum contamination was greater than the expected urinary output per 24 hours. The plastic 'tie-pant' was heavily contaminated with cadmium and therefore required deionizing before use.

After soaking for 24 hours in $0 \cdot 1 \mathrm{~N} \mathrm{HCl}$ solution the nappy had partially disintegrated. Therefore, the use of the chelating agent ethylene diamine tetraacetic acid (EDTA) to remove the metals from the nappy was investigated.

Experiment 2: to investigate the removal of metals from the nappy

Samples $(50 \mathrm{~g})$ of wood pulp, used to make the centre of the nappies, were broken up, placed in ? $500 \mathrm{ml}$ flasks, covered with $400 \mathrm{ml} 0 \cdot 1 \mathrm{M}$ EDTA $(p \mathrm{H} 6-7)$ and agitated occasionally for two hours. The supernatant solution was poured off and retained. The pulp was squeezed by hand and then $\frac{\circ}{\partial}$ covered with $400 \mathrm{ml}$ water in a clean flask. After $\vec{Z}$ thorough mixing the pulp was again squeezed and $Z$ the washings were retained. This was repeated a $ळ$ further three times and the pulp was soaked overnight in $400 \mathrm{ml} 1 \% \mathrm{HCl}$ solution. This supernatant $\stackrel{\mathbb{\Phi}}{-}$ solution was poured off and all six eluates were $\overrightarrow{0}$ analysed directly for their metal content. Blank samples from the reagent and flask were alsi analysed.

The results for calcium, magnesium, and zinc afe shown in Figure 2. The degree to which the whole nappy was deionized for each metal was determined by a similar experiment and the results are recorded in Table II.

The decontamination of the nappies proved to be satisfactory for all metals except iron. The reason

\begin{tabular}{|c|c|c|c|c|c|c|c|c|c|c|c|c|}
\hline Metal & $\mathrm{Ca}$ & $M g$ & $\mathrm{Fe}$ & $Z_{n}$ & $C u$ & $M n$ & $\mathrm{Ni}$ & $\mathrm{Co}$ & Mo & $\mathrm{Cr}$ & $C a l$ & $P b$ \\
\hline $\begin{array}{l}\text { Metal per nappy }(\mu \mathrm{g}) \\
\text { Maximum ( } \mu \mathrm{g}) \text { con- } \\
\text { tamination from six }\end{array}$ & 4000 & 500 & 57 & 18 & 9 & 12 & 19 & 8 & $<3$ & Not Done & 16 & 134 \\
\hline $\begin{array}{l}\text { nappies } \\
\text { Expected 24-hr urine }\end{array}$ & 24000 & 3000 & 342 & 108 & 54 & 72 & 114 & 48 & $<18$ & Net Done & 96 & 804 \\
\hline $\begin{array}{l}\text { excretion }(\mu \mathrm{g})^{1} \\
\text { Contamination of }\end{array}$ & 14000 & 16000 & 38 & 108 & 42 & 7 & 36 & 27 & 37 & Not Done & 8 & 45 \\
\hline 'tie-pant' $(\mu \mathrm{g})$ & -1 & 7 & 5 & +2 & $2 \cdot 4$ & .1 & $<3$ & 2 & .2 & Not Done & 86 & . 3 \\
\hline
\end{tabular}

Table I Metal contaminant of nappies hefore preparation

${ }^{1}$ Geigy Medical \& Scientific Tables

\begin{tabular}{|c|c|c|c|c|c|c|c|c|c|c|c|c|}
\hline Metal & $\mathrm{Ca}$ & $M g$ & $\mathrm{Fe}$ & $Z n$ & $C u$ & $M n$ & $\mathrm{Ni}$ & $\mathrm{Co}$ & $\mathrm{Cr}$ & Mo & $C d$ & $P b$ \\
\hline Metal per untreated nappy ( $\mu \mathrm{g})$ & 1880 & 430 & 58 & 2 & 15 & 25 & $1 \cdot 1$ & $<0.1$ & $0 \cdot 2$ & $<0.13$ & 0.7 & 143 \\
\hline Metal per treated nappy $(\mu \mathrm{g})$ & 40 & 20 & $4 \cdot 8$ & 0.09 & 0.12 & 0.10 & $<0.1$ & $<0.1$ & $<0.05$ & $0 \cdot 13$ & $0 \cdot 16$ & 1.7 \\
\hline $\begin{array}{l}\text { Decontamination factor } \\
\text { Maximum contamination }(\omega \mathrm{g})\end{array}$ & 45 & 21 & 13 & 22 & 61 & 250 & .11 & -- & .4 & $\therefore$ & 4 & 86 \\
\hline per six treated nappies & 252 & 120 & 29 & 0.5 & 0.72 & 0.6 & $<0.6$ & $<0.1$ & $<0.3$ & $<0.8$ & 1.0 & 10 \\
\hline
\end{tabular}

Table II Decontamination of nappies with EDT.A 
$\mathrm{Zn} \mathrm{Mg} \mathrm{Ca}$

$(\mu g \%)(\mu g \%)(M g \%)$

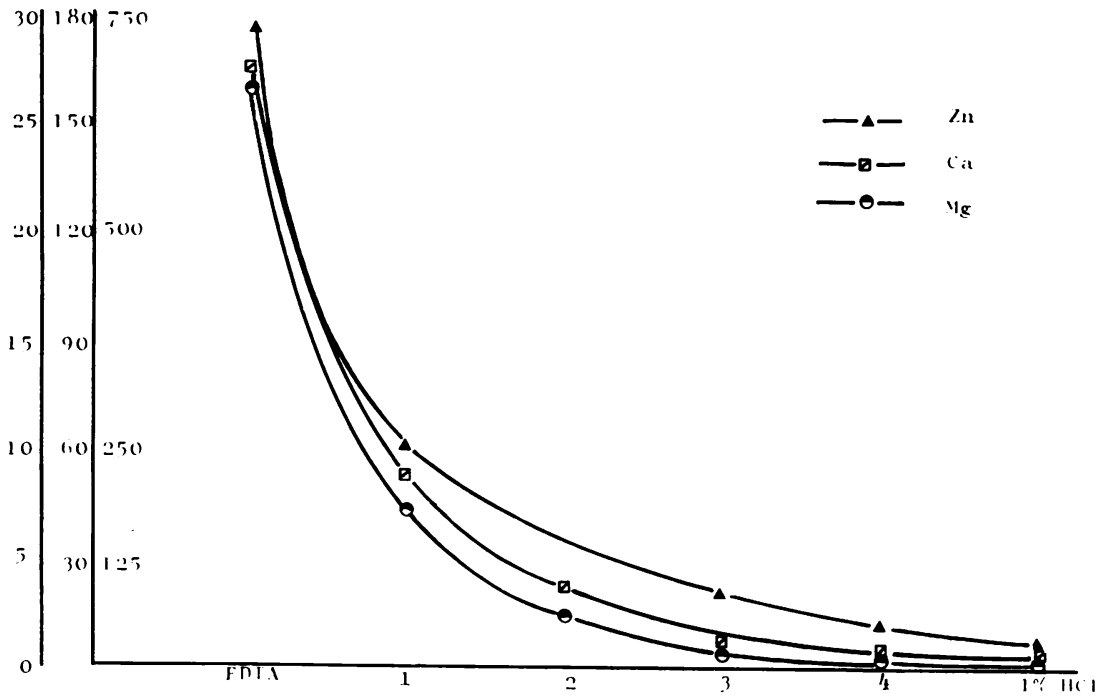

Fig. 2 The deionization of the nappy.

Fig. 3 The recovery of metals from the nappy at different $\mathrm{pH}$ values.

Key: $\bigcirc \mathrm{Fe} ; \mathrm{O} \mathrm{Mn}$;

$\triangle \mathrm{Zn} ; \square \mathrm{Cu} ; \times \mathrm{Ni}$;

$\infty \mathrm{Cd} ; \triangle \mathrm{Cr} ; \odot \mathrm{Co}$;

Mo.

Fig. 2.

Reagents for clution

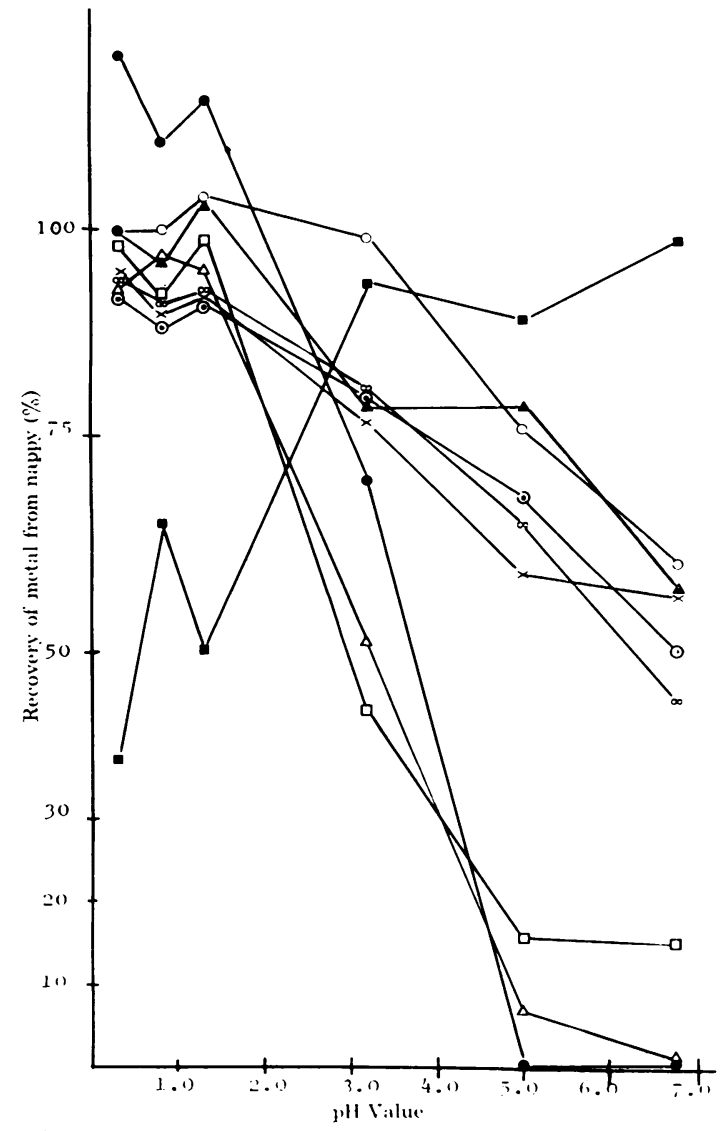

Fig. 3. for this is probably that the wood pulp fluff contains a number of small particles of stainless steel worn off the shredding blades used in the fluffing process, and these would be insoluble in EDTA.

Experiment 3: to investigate the conditions for inaximum recovery of the metals

Five $\mathrm{g}$ portions of the nappy were placed into each of $6 \times 500 \mathrm{ml}$ beakers. Six standard solutions containing $6 \mu \mathrm{g} / \mathrm{ml}$ of all the metals under investigation were adjusted to six different $p \mathrm{H}$ values (from 0.3 to $6 \cdot 8)$. Half of each solution $(100 \mathrm{ml})$ was then added to a nappy portion and allowed to equilibrate for 48 hours; the other half was stored at room temperature in a glass container. The portions of nappy were then squeezed out and the concentration of the metals was determined directly. The recuvery of the metals from the nappy was calculated from a comparison of the concentration of the metals found in the eluates with the concentration in the unused standards.

The variation of percentage recovery with $p \mathrm{H}$ is shown in Figure 3. At $p \mathrm{H}<1.3$, the recovery was $100 \%$ for all metals except molybdenum; at $p \mathrm{H}>5$, the recovery of this metal was $>90 \%$, but there was hydrolysis and precipitation of most of the other metals. Thus maximum elution of all metals could only be obtained by using two elutions, the first at $p \mathrm{H}>1$, the second at approximately $p \mathrm{H} 3$. This was confirmed by a further experiment, when the recovery of molybdenum was 95 to $97 \%$ and of the other metals was 97 to $100 \%$. 
PREPARATION OF THE NAPPIES

One vat was half-filled with $0 \cdot 1 \mathrm{M}$ EDTA solution and the other four were two-thirds filled with deionized water; all were covered with polythene to exclude dust. Twenty nappies were placed in a coarse mesh nylon bag, which was then immersed for 24 hours in the EDTA solution. After squeezing between reinforced sheets of polythene it was placed in the second vat for a further 24 hours, squeezed again, and transferred to a third vat to which $5 \mathrm{ml}$ chloroform had been added to inhibit bacterial growth. The nappies were subsequently transferred to a fourth water wash, squeezed and then placed flat on the wire mesh racks and dried in the oven at $80^{\circ} \mathrm{C}$. When dry, usually after two days, they were 'fluffed up' by hand and placed in pairs into polythene bags for storage.

Three nappies from each batch were stored separately to determine the residual mean contamination of the 20 nappies prepared.

'Tie-pants' were soaked in $10 \% \mathrm{HNO}_{3}$ and then rinsed four times in water. They were dried by hand with medical tissues.

\section{Results}

The residual contamination is shown in Table III. The final state of the nappy was altered very little by the process; it remained clean and white and

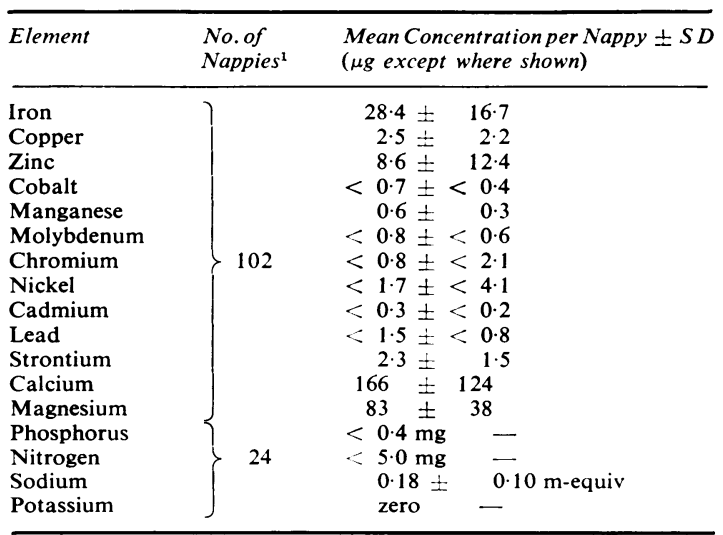

Table III Mean residual concentration of elements in the nappies after preparation

${ }^{1} 3$ nappies tested from each batch of 20

the absorbency for water was reduced by approximately $25 \%$.

PROCEDURE FOR COLLECTION OF EXCRETA AND ITS APPLICATION IN TWO CHILDREN

At the start of the balance, the deionized nappy was placed around the child's perineum with the fold in the cover on the outside, and held in place by the specially prepared 'tie-pant'. Nappies containing urine only were collected into a fine mesh nylon bag, soaking in $500 \mathrm{ml}$ of $1 \% \mathrm{HCl}$ solution in a polythene bucket. The bucket and contents had been weighed previously and it was changed every 24 hours.

As much of the solid faeces as possible was removed from the nappy using a polythene spatula. The soiled cover was stripped off and retained separately. The cover was subsequently washed with water and the washings used to dilute the faeces during homogenization. The centre of the soiled nappy was placed in the nylon bag together with the nappies containing urine only. When the faeces were well formed it was possible to separate completely the faecal and urinary excreta. With the more fluid on faeces there was always some staining of the central portion of the nappy and this was analysed with the urine.

At the end of each 24-hour period, the bucket and 을 nappies used were weighed and the weight of urine passed during the 24 hours was calculated by sub- $z$ tracting from this the original weight of the bucket and the total weight of nappies used (less any soiled covers). The contents of the bucket were then $\mathbb{Q}$ covered with $1 \% \mathrm{HCl}$ and left to equilibrate for one $\vec{\omega}$ hour. The nylon bag was squeezed out, retaining the eluate, replaced, and covered with deionized wates After a further one hour's equilibration the nappis were again squeezed out and the two eluates conbined. The final weight of this pooled eluate was recorded.

ANALYSIS

Duplicate $50 \mathrm{ml}$ samples of the pooled eluate were evaporated to dryness on a sand bath at $120^{\circ} \mathrm{C}$ and ashed in a muffle furnace overnight at $500^{\circ} \mathrm{C}$. The residues were dissolved in $\mathrm{HCl}$ and diluted to a fixed volume, and the metals determined.

\section{SUBJECTS}

C.B., a healthy girl, aged 1 year, lived in a residential children's home, and A.K., a 13-month-old girl with branched chain ketonuria (Maple syrup urine disease) was in hospital on a special diet.

The technique described above has been used satisfactorily for a further 11 balance studies, the $\mathcal{N}$ results of which will appear separately.

\section{Results}

The final 24-hour urinary excretion for any element $\stackrel{\circ}{C}$ is calculated by subtracting the contamination for $\stackrel{\mathbb{N}}{\rightleftharpoons}$ the total number of nappies used from the metal content of the pooled eluate as shown for the two children in Table IV. 


\begin{tabular}{|c|c|c|c|c|c|c|}
\hline \multirow[t]{2}{*}{ Element } & \multicolumn{3}{|l|}{ Subject C.B. } & \multicolumn{3}{|l|}{ Patient A.K. } \\
\hline & Combined Eluate & Nappy Blank & Urinary Excretion & Combined Eluate & Nappy Blank & $\begin{array}{l}\text { Urinary } \\
\text { Excretion }\end{array}$ \\
\hline $\mathbf{N}(\mathrm{g})$ & $7 \cdot 45$ & 0.09 & $7 \cdot 36$ & 6.42 & 0.14 & $6 \cdot 28$ \\
\hline $\mathbf{P}$ (mg) & $870 \cdot 8$ & $7 \cdot 2$ & 863.6 & $741 \cdot 2$ & 10.8 & 730.4 \\
\hline $\mathrm{Na}$ (m-equiv) & $73 \cdot 3$ & $3 \cdot \overline{2}$ & $70 \cdot 1$ & $52 \cdot \overline{7}$ & 4.9 & $47 \cdot 8$ \\
\hline $\mathbf{K}$ (m-equiv & 54 & 0 & 54 & $41 \cdot 7$ & 0 & $41 \cdot 7$ \\
\hline $\mathrm{Ca}(\mathrm{mg})$ & $42 \cdot 5$ & 0.59 & 41.91 & $74 \cdot 1$ & $12 \cdot 2$ & $61 \cdot 9$ \\
\hline $\mathrm{Mg}(\mathrm{mg})$ & $63 \cdot 2$ & 0.58 & 61.62 & 85 & $2 \cdot 2$ & $82 \cdot 8$ \\
\hline $\mathrm{Fe}$ (mg) & 1.05 & 0.45 & 0.60 & 0.80 & 0.90 & 0 \\
\hline $\mathrm{Zn}$ (mg) & 0.52 & 0.02 & 0.50 & $2 \cdot 39$ & $1 \cdot 30$ & $1 \cdot 10$ \\
\hline $\operatorname{Mn}(\mu \mathrm{g})$ & $45 \cdot 9$ & $12 \cdot 5$ & $33 \cdot 4$ & $42 \cdot 7$ & $11 \cdot 1$ & 31.6 \\
\hline $\mathrm{Cu}(\mu \mathrm{g})$ & $88 \cdot 9$ & $37 \cdot 0$ & 51.9 & $83 \cdot 4$ & 45.9 & $37 \cdot 5$ \\
\hline $\mathrm{Pb}(\mu \mathrm{g})$ & $108 \cdot 4$ & 30.5 & $78 \cdot 0$ & 163.0 & 40.0 & 123.0 \\
\hline Mo $(\mu \mathrm{g})$ & $51 \cdot 7$ & $8 \cdot 7$ & 43.0 & $51 \cdot 0$ & 11.0 & $40 \cdot 0$ \\
\hline $\operatorname{Cr}(\mu \mathrm{g})$ & $21 \cdot 6$ & $6 \cdot 1$ & $15 \cdot 5$ & $26 \cdot 4$ & $8 \cdot 1$ & $18 \cdot 3$ \\
\hline $\operatorname{Sr}(\mu \mathrm{g})$ & $64 \cdot 1$ & $9 \cdot 1$ & $55 \cdot 0$ & 133.0 & $62 \cdot 0$ & $71 \cdot 0$ \\
\hline $\mathrm{Cd}(\mu \mathrm{g})$ & $22 \cdot 4$ & 2.4 & 20.0 & 14.4 & $4 \cdot 1$ & $10 \cdot 3$ \\
\hline $\operatorname{Co}(\mu \mathrm{g})$ & 13.9 & 0.9 & 13.0 & $48 \cdot 2$ & $14 \cdot 2$ & $34 \cdot 0$ \\
\hline $\mathrm{Ni}(\mu \mathrm{g})$ & $76 \cdot 0$ & $6 \cdot 0$ & $70 \cdot 0$ & $39 \cdot 6$ & $13 \cdot 5$ & $26 \cdot 1$ \\
\hline
\end{tabular}

Table IV Concentration of elements in the three-day eluate and total nappy blanks for two children under investigation

For the major elements (nitrogen, phosphorus, sodium, potassium, calcium and magnesium) the maximum contamination from the nappies was $0-5 \%$ of the urinary excretion. The contamination from most of the trace metals was up to $40 \%$ of the urinary excretion. For four of the trace metals (iron, zinc, chromium, strontium) the maximum nappy blank was equal to or slightly greater than the urinary excretion for one of the two children.

\section{Discussion}

Iron was the only metal which was difficult to remove from the nappy and consistently high blanks were observed. However, even when the nappy blank was as high as the urinary excretion, the accuracy of the blank value was sufficiently good (Table III) for the urinary excretion to be calculated with confidence. The fact that, with the exception of lead, molybdenum, cadmium and cobalt, the urinary excretion of the trace metals is far smaller than the faecal excretion, further decreases the percentage error of a high blank result.

Some slight contamination of urine with faeces was inevitable, particularly with a child with loose stools. However, this was of little consequence since we were interested in the total amounts of the minerals excreted.

The use of deionized disposable nappies has given us the opportunity to perform trace metal balance studies upon normal and abnormal children in their natural environment. There was no need to immobilize the infants, nor to use any additional apparatus; the collection of urine was no more difficult from the girls than from the boys. It is an extremely simple and effective technique; it has been welcomed enthusiastically by the nursing staff on the Metabolic Ward and it has reduced their work load.

Balances performed in the past on children up to 3 years of age have usually been limited to short periods because of the deterioration in the state of the perineal skin. It is now possible to perform much longer balances since there is no such deterioration in skin condition; indeed the perineum of one child, under investigation, improved during the balance period. This is an important observation since the use of creams and powders is prohibited during any mineral balance.

Although the method of collection was originally designed for trace element balances, it has been shown to be equally useful for the investigation of nitrogen, phosphorus, sodium, and potassium. It would probably be applicable to faecal collections for fat but this has yet to be confirmed.

We should like to thank Mr D. Granville-Jolly of Lewis Woolf (Griptite Ltd) for his help and generosity in the donation of nappies; also $\mathrm{Mr}$ B. Goodwin of Stora Kopparbergs for his technical advice.

We are indebted to Mrs $\mathbf{P}$. Edwards, $\mathrm{Mr} \mathbf{J}$. Mitchell, and Mrs J. Skehens for their technical assistance, and Professor Barbara E. Clayton for her continued advice and encouragement throughout the project and in the preparation of the paper.

Financial assistance from the Medical Research Council is gratefully acknowledged.

\section{References}

Berfenstam, R. (1952). Studies on blood zinc. Acta paediat., 41, Suppl. 87. 
Briggs, A. P. (1922). A modification of the Bell-Doisy phosphate method. J. biol. Chem., 53, 13-16.

McCance, R. A., Rutishauser, I. H. E., and Boozer, C. N. (1970). The effect of kwashiorkor on absorption and excretion of nitrogen fat and minerals. Arch. Dis. Childh., 45, 410-416.

Millard, F. J. C., Nassim, J. R., and Woollen, J. W. (1970). Urinary calcium excretion after immobilisation and spinal fusion in a dolescents. Arch. Dis. Childh., 45, 399-403.

Rose, G. A. (1966). Immobilisation osteoporosis: a study of the extent, severity, and treatment with bendrofluazide. Brit. J. 으 Surg., 53, 769-774.

Widdowson, E. M. (1965). Absorption and excretion of fat, nitrogen and minerals from 'filled' milks by babies one week old. Lancet, $\vec{\oplus}$ 2, 1099-1105.

\section{The October 1972 Issue}

\section{THE OCTOBER 1972 ISSUE CONTAINS THE FOLLOWING PAPERS}

Isolation of a mycoplasma from sarcoid tissue ELLI JANSSON, MATTI HANNUKSELA, HANS EKLUND, HELENA HALME, AND SIRKKA TUURI

Immunofluorescence for routine diagnosis of respiratory syncytial virus infection G. E. D. URQUHART AND G. H. WALKER

A fluorescent antibody test in the diagnosis of farmer's lung D. PARRATT AND J. A. PEEL

Liver morphology in acute viral hepatitis related to the hepatitis B antigen S. IWARSON, P. LUNDIN, AND S. HERMODSSON

Observations on a new family showing bisalbuminaemia of the slow type TERESA MIKULSKA, PAWEL MIKULSKI, AND JERZY ROGULSKI

Changes in the normal range of thyroidal radioiodine uptake D. H. KEELING AND E. S. WILLIAMS

Increased brain weight/liver weight ratio as a necropsy sign of intrauterine undernutrition JOHN M. ANDERSON

Acute villous inflammation in the placenta following intrauterine transfusion JEAN M. SCOTT AND A. HENDERSON

Starch and talc emboli in drug addict's lungs LAMB AND G. ROBERTS

A case of abortion consequent upon infection with Brucella abortus biotype 2 PAULINE M. POOLE, D. B. WHITEHOUSE, AND MARGARET M. GILCHRIST

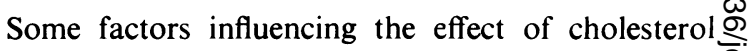
on streptolysin $O$ activity K. C. WATSON, T. P. 용 ROSE, AND E. J. C. KERR

The role of creatinine and histidine in Benedict's qualitative test for reducing sugar in urine B. K. N SUR, R. K. SHUKLA, AND V. S. AGASHE

Mode of action of creatinine on colour of cuprous $\bar{z}$ oxide precipitate in Benedict's qualitative sugar test B. K. SUR, R. K. SHUKLA, AND V. S. AGASHE

A rapid micro-method for the screening and measurement of barbiturates and related compounds in plasma by gas-liquid chromatography R. J. FLA N AGAN AND G. WITHERS

\section{Present day practice}

Problems in quality control in determinations of serum total iron-binding capacity by the magnesium carbonate method J. LEGGATE AND A. E. CROOKS

Routine determination of $5^{\prime}$ nucleotidase activity of human serum using the LKB 8600 reaction rate analyser D. M. GOLDBERG AND G. ELLIS

\section{Technical methods}

A simple method for chromosome banding $E$. GRACE AND A. D. BAIN

Technique for the performance of the nitro-blue 9 tetrazolium (NBT) test R. FREEMAN AND B. KING

Reprocessing of wax-embedded tissue blocks for the electron microscope applied to Crohn's disease

T. WATSON, M. J. FULKER, AND M. G. COOK

Letters to the Editor

Book reviews

Copies are still available and may be obtained from the PUBLISHING MANAGER, BRITISH MEDICAL ASSOCIATION, TAVISTOCK SQUARE, LONDON, WC1H 9JR, price $£ 1.05$ 